\title{
Hepatitis $C$ seropositivity among newly incarcerated prisoners in Estonia: data analysis of electronic health records from 2014 to 2015
}

\author{
Kristel Kivimets $^{1 *}$ (D), Anneli Uusküla ${ }^{2}$, Jeffrey V. Lazarus ${ }^{3,4}$ and Kristi Ott ${ }^{5}$
}

\begin{abstract}
Background: Hepatitis C virus (HCV) infection is a widespread problem in prisons. The present study aimed to assess the prevalence of HCV seropositivity, HCV genotypes, factors associated with HCV seropositivity in newly incarcerated prisoners and to report experiences of treatment with pegylated interferon/ribavirin for HCV-positive inmates.

Methods: Patient data were extracted from the Estonian prison medical information system (Vanglate meditsiiniline infosüsteem) databases.

Results: Among 1845 prisoners newly incarcerated from January 2014 to January 2015, the overall prevalence of HCV was 56.3\% (95\% Cl: 54 to 59), and 25.5\% (95\% Cl: 23.5 to 27.6\%) had HIV (39.0\% had neither). The all-inclusive HCV testing strategy identified $37.7 \%$ more HCV infected prisoners than the risk-based (drug use history, HIV status) case finding. Factors associated with HCV seropositivity included history of drug use (aOR 6.51 95\%Cl 5.12-8.28), HIV coinfection (aOR 2.56 95\% Cl 1.92-3.43), previous incarceration (aOR $3.6195 \% \mathrm{Cl} 2.48-4.04)$, and increasing age. The main HCV genotypes were $3 \mathrm{a}(n=172,44.4 \%)$ and $1 \mathrm{~b}(n=135,35.2 \%)$. Twenty-five prisoners received HCV treatment: 60\% $(n=15)$ were cured, 16\% $(n=4)$ relapsed (3 with genotype $3 a$, one with $1 b)$, and 12\% $(n=3)$ were unresponsive (all with genotype 3a).

Conclusions: HCV seropositivity rate is high and HCV tretment rate is very low in Estonian prisons. Optimizing case finding and scaling up treatment is critical to addressing the health needs of prisoners and meeting public health goals.
\end{abstract}

Keywords: Prison health, Viral hepatitis, Hepatitis C, HIV, Case finding, Estonia

\section{Background}

Hepatitis $\mathrm{C}$ virus (HCV) infection is an escalating global health issue and prisoners are emerging as an important high-risk group. HCV prevalence in this subpopulation ranges from 3 to $38 \%[1,2]$. Although this high burden of $\mathrm{HCV}$ is gaining notoriety and modern treatment can provide noticeable improvements in the health statuses of most patients, many countries still lack HCV prevalence data for high-risk groups. Epidemic patterns of $\mathrm{HCV}$ infection related to injection drug use persist in Europe. Understanding the risk factors for HCV infection among

\footnotetext{
* Correspondence: kristel.kivimets@tai.ee

${ }^{1}$ National Institute for Health Development, 42, 11619 Tallinn, Hiiu, Estonia Full list of author information is available at the end of the article
}

prisoners may inform $\mathrm{HCV}$ prevention and treatment intervention measures [2-5].

$\mathrm{HCV}$ prevalence is higher among prisoners than in the general population [2]. Intravenous drug use (IDU) is one of the major risk factors for $\mathrm{HCV}$ infection. The prevalence of IDU in prisons is ranging from 2 to $38 \%$ in Europe while the relevant percentage in the general population is estimated at $0.3 \%$ in the European Union and $0.2 \%$ in Australia. [6]. A metaanalysis showed that people who inject drugs (PWID) were about 24 times more likely to be infected with HCV than individuals in the general population in Europe [7]. IDU [8] and tattooing $[9,10]$ are the main risk behaviours for acquiring $\mathrm{HCV}$ infection in prisons.

(c) The Author(s). 2018 Open Access This article is distributed under the terms of the Creative Commons Attribution 4.0 International License (http://creativecommons.org/licenses/by/4.0/), which permits unrestricted use, distribution, and reproduction in any medium, provided you give appropriate credit to the original author(s) and the source, provide a link to the Creative Commons license, and indicate if changes were made. The Creative Commons Public Domain Dedication waiver (http://creativecommons.org/publicdomain/zero/1.0/) applies to the data made available in this article, unless otherwise stated. 
Prisoners with human immunodeficiency virus (HIV) are more likely to be infected with $\mathrm{HCV}$ probably because of the similarity in the routes of transmission of these blood-borne infections [1, 3]. According to recent studies in Italian and US prisons, the $\mathrm{HCV}$ prevalence was more than four times higher among HCV-HIV coinfected patients than among those not infected with HIV (65.5-89.6\% vs. $15.5-27.5 \%$, respectively) $[3,11]$.

Another risk factor related to $\mathrm{HCV}$ infection is repeated incarceration [12, 13], an association that may be confounded by low socioeconomic status, poor access to health care, high-risk sexual behaviors and injection drug use [14].

In some studies $\mathrm{HCV}$ infection was observed more frequently in female inmates than in males. [1]. In part that may have been because the number of women in prison has grown and women prisoners are more likely than their male counterparts to have been incarcerated for drug offences [15] and to have serious drug-related health problems [16], including infectious diseases [17].

Direct-acting antivirals (DAAs) are relatively new and expensive, but cost-effective when well utilised as interventions for chronic hepatitis $C$, and preliminary results suggest that DAAs may eradicate HCV from the blood (sustained virological response). The effect of long-term treatment with DAA (hepatitis $\mathrm{C}$ morbidity and mortality) is yet to be convincingly demonstrated [18]. Still, ribavirin has been an integral component of treatment for hepatitis $\mathrm{C}$ virus ( $\mathrm{HCV}$ ) infection, and the safety profile of ribavirin is improved when co-administered with all-oral DAA combinations in the absence of interferon [19]. Several studies have shown that prisoners can be effectively treated for HCV infection [20-22], although treatment is administered less frequently to prisoners because of the cost of treatment, treatment often exceeding average prison stay combined with a lack of continuity of care, and unawareness of the $\mathrm{HCV}$ infected status of the prisoners [1].

Most HCV infected people are unaware of their condition [23]. Prisons may be a good venue to detect many of those cases. Although exact data are not available, each year, up to one million people with undiagnosed $\mathrm{HCV}$ infection may come into contact with the correctional system in the United States [24]. Strategies of case finding should be developed that are based on current infections rates and feasibility.

\section{The situation in Estonian prisons}

The prison population in Estonia has stabilised at nearly 3000 individuals in recent years but the incarceration rate, with 222 prisoners per 100,000 population, still remains very high. According to the Council of Europe's annual penal statistics, the highest incarceration rates in Europe are recorded in the former Soviet Union countries (439 per 100,000 population in the Russian Federation, 277 per
100,000 in Lithania, 274 per 100,000 in Georgia, 248 per 100,00 in Azerbaijan and 223 per 100,000 in Latvia) [25].

Needle and syringe exchange programmes (NSP) in Estonia were launched in 1997. In addition to NSP, condom distribution, different counselling services incl. social, health, psychological, legal, experience counselling), basic humanitarian aid, primary hygiene possibilities [26], naloxone take-home program training (since 2013), and motivation and referral to treatment/rehabilitation are offered under harm reduction services in Estonia. From 2015, naloxone is available also in prisons [27]. In all Estonian prisons, opioid substitution therapy (OST) in the form of methadone treatment is provided. NSP are not operating in Estonian prisons [28].

According to the Estonian Ministry of Justice, there were 3580 prisoners in Estonia's four prisons during the period between 1 January 2014 and 1 January 2015 (personal communication with Asko Oruste, the information systems manager with Estonian IT Support System). A study conducted in Estonia in 2012-2013 found that, of all prisoners, one-third had a history of drug use, $15.6 \%$ were infected with HIV and, of those that were HIV-positive, $54.1 \%$ were receiving antiretroviral therapy (ART) [28].

The implementation of the project "Improvement of Prevention and Treatment of Infectious Diseases in Estonian prisons" [29] targeting testing, treatment and infrastructure buildings was a milestone in the diagnosis and care of $\mathrm{HCV}$ in prisons [30]. Before that, $\mathrm{HCV}$ testing targeted only prisoners considered at high risk for HCV (identified by their drug use history or HIV status; "the old testing strategy") (personal communication with Maret Miljan from the rehabilitation department of the Estonian prison department,). Since the launch of the project in January 2014, $\mathrm{HCV}$ tests have been offered for all newly incarcerated prisoners ("the new testing strategy").

The aim of this study was to assess the prevalence of $\mathrm{HCV}$ seropositivity and its related factors among newly incarcerated prisoners and to describe the effects of treatment of $\mathrm{HCV}$ infection in Estonian prisons.

\section{Methods}

This study was carried out from 1 January 2014 to 1 January 2015. The term 'newly incarcerated prisoner' is used for all people, including adults and juveniles, detained during the investigation of a crime, while awaiting trial, after conviction, before sentencing and after sentencing, and incarcerated in one of the four Estonian prisons.

\section{Data and data sources}

For this study we relied on the secondary data available in the administrative and health databases of the Estonian prison medical information system. 


\section{Prison electronic patient database}

The prison electronic patient database is designed for prison healthcare and contains electronic health records. For those tested for $\mathrm{HCV}$, the following data were extracted from prisoners' health records: (i) $\mathrm{HCV}$ test result, (ii) HCV genotype, (iii) age, (iv) gender, (v) HIV serostatus, (vi) history of drug use (based on the International Classification of Diseases codes F11-F16 or F18-F19), and (vii) HCV treatment results. HCV in prisons is treated by prison infectious diseases physicians who also make HCV-genotype testing decisions.

For all samples collected in the prison medical information system over the study period, HIV testing (VironostikaHIV Uniform II Ag/Ab, BioMerieux method), anti-HCV antibodies testing (Siemens, A HCV200T KIT), and HCV genotyping (The VERSANT ${ }^{\ominus} \mathrm{HCV}$ Genotype 2.0 Assay) were performed at Synlab Estonia (an accredited laboratory following the requirements of ISO 15189 Medical Laboratories).

\section{Database of prisoners, detained persons, persons in custody and probationers}

Data on tattoos and previous incarceration were extracted from the databases of prisoners, detained persons, persons in custody and probationers (hereinafter referred to as the prisoners' register). The prisoners' register is an electronic database containing selected information on the details of prison sentence as well as personal data. Information on tattoos included in the register is based on inspection of prisoners' skin at prison entry.

\section{Statistical analysis}

Descriptive statistics are presented for categorical variables (absolute number (n) and relative frequencies (\%)) and continuous variables (mean, standard deviation and range). A chi-squared test was used to explore differences in categorical variables and the Wilcoxon rank sum test for age comparisons between the HCV infected and non-infected groups. Associations between antibodies to HCV (the outcome of interest) and covariables were explored bivariably and multivariably (by including all independent variables in the model) by logistic regression analyses. Odds ratios (OR) and adjusted OR (AOR) together with 95\% confidence intervals (CI) are presented. Associations between covariables were also tested to assess the reliability of the multivariate models (according to the possibility of multicollinearity). The statistical software program SPSS version 16.0 (Chicago, Illinois, USA) was used.

\section{Results}

\section{HCV and HIV diagnosis}

Between 1 January 2014 and 1 January 2015, 1957 new prisoners were admitted to the Estonian prison system. Of those, 603 were already infected with HCV (based on data from previous testing in prison). As per the new testing strategy, the rest of the newly imprisoned individuals $(n=$ 1242) were tested for $\mathrm{HCV}$ with the exception of 112 prisoners (26 prisoners declined testing and the reason for not testing was unknown for the other 86).

The final sample consisted of 1845 newly incarcerated prisoners with known HCV status. They had an average age of 35 years $(\mathrm{SD}=11.54$, range $15-78)$. Of these prisoners, $94.4 \%$ were male $(n=1742), 58.1 \%$ had previously used illicit drugs $(n=1034), 28.1 \%$ were tattooed $(n=$ $519)$, and $68.9 \%$ had been previously incarcerated $(n=$ $1272)$. The prevalence of HCV seropositivity was $56.3 \%$ $(n=1038,603+435)$ and the prevalence of HIV $25.5 \%$ (95\% CI $23.5-27.6 \%)(n=469)$. One fifth $(n=379 ; 20.5$, 95\% CI $19.8-23.6 \%)$ of the newly incarcerated prisoners had HCV-HIV co-infections. The majority $(80.8,95 \% \mathrm{CI}$ 77.2-84.4\%) of the HIV-positive prisoners were also infected with HCV (Table 1).

The old testing strategy - high-risk based case finding - would have identified only $37.7 \%$ (164/435) of the $\mathrm{HCV}$ infected newly incarcerated prisoners. While comparing $\mathrm{HCV}$ infected and non-infected newly incarcerated prisoners, we found that $\mathrm{HCV}$-infected prisoners tended to be slightly older, and were more likely to have a tattoo $(63.8 \%$ vs $36.2 \%, p<0.001)$, to have a history of drug use $(76.6 \%$ vs $23.4 \% ; p<0.001)$, to be HIV-infected ( $80 \%$ vs $19.2 \%, p<0.001)$, and to have previously been incarcerated $(65.1 \%$ vs $4.9 \%, p<0.001)$. There were no gender differences in HCV seropositivity (Table 2).

After adjustment, history of drug use emerged as the factor most strongly associated with HCV seropositivity (AOR 6.51 95\% CI 5.12-8.28). The risk of HCV seropositivity was also significantly higher among those who were HIV-positive (AOR 2.56 95\% CI 1.92-3.43) and those previously incarcerated (AOR 3.16 95\% CI 2.484.04). The risk of $\mathrm{HCV}$ positivity increased with age. While tattooing was associated with the $\mathrm{HCV}$ rates in the bivariable analysis, this association was not found in the multivariable analysis.

\section{HCV genotypes}

Of the 1038 prisoners who tested positive for HCV, 383 (36.9\%) underwent HCV genotype testing. The main genotypes identified were $3 \mathrm{a}(44.4 \%, n=172)$ and $1 \mathrm{~b}(35.2 \%$, $n=135)$. A further $17 \%(n=65)$ had genotype $1 \mathrm{a}$, and $2.6 \%$ prisoners $(n=10)$ had genotype 2 . Only one prisoner had HCV genotype 4.

\section{HCV treatment}

Between 1 January 2014 and 1 January 2015, all HCV cases, 25 prisoners (24 male and 1 female), received HCV treatment (pegylated interferon (PEG-INF) and ribavirin). The decision to treat was reached after an in-depth, individualized process including informed consent and considering 
Table 1 Factors associated with hepatitis C infection among newly incarcerated prisoners in Estonia, 2014 to 2015 ( $n=1845)$

\begin{tabular}{|c|c|c|c|c|}
\hline Variable & All $N=1845$ & $\mathrm{HCV}+{ }^{\mathrm{b}}(\mathrm{n} ; \%)$ & $\mathrm{HCV}^{\mathrm{c}}(\mathrm{n} ; \%)$ & $p$-value (HCV + vs HCV-) \\
\hline Age (mean; SD) & $34.1 ; 10.92$ & $35.66 ; 11.49$ & $34.11 ; 11.56$ & $p<0.001$ \\
\hline Gender (male: n; \%) & $1742 ; 94.4 \%$ & $978 ; 56.1 \%$ & $764 ; 43.9 \%$ & $p=0.675$ \\
\hline \multicolumn{5}{|l|}{ Age group } \\
\hline $15-20$ & 107 & $36 ; 33.6 \%$ & $71 ; 66.4 \%$ & \\
\hline $21-30$ & 620 & $330 ; 53.2 \%$ & $290 ; 46.8 \%$ & \\
\hline $31-40$ & 494 & $304 ; 61.5 \%$ & $190 ; 38.5 \%$ & \\
\hline $41-50$ & 304 & $177 ; 58.2 \%$ & $127 ; 41.8 \%$ & \\
\hline $51-60$ & 183 & $103 ; 56.3 \%$ & $80 ; 43.7 \%$ & \\
\hline $61-70$ & 30 & $25 ; 83.3 \%$ & $5 ; 16.7 \%$ & \\
\hline $71-78$ & 4 & $3 ; 75 \%$ & $1 ; 25 \%$ & \\
\hline Tattoo (yes: n; \%) & $519 ; 28.1 \%$ & $331 ; 63.8 \%$ & $188 ; 36.2 \%$ & $p<0.001$ \\
\hline Drug use history (yes: n; \%) & $1034 ; 56.2 \%$ & $819 ; 76.6 \%$ & $250 ; 23.4 \%$ & $p<0.001$ \\
\hline HIV infected (n; \%) & $469 ; 25.5 \%$ & $379 ; 80.8 \%$ & $90 ; 19.2 \%$ & $p<0.001$ \\
\hline Previous incarceration (yes: n; \%) & $1271 ; 68.9 \%$ & $827 ; 65.1 \%$ & $444 ; 34.9 \%$ & $p<0.001$ \\
\hline
\end{tabular}

${ }^{\mathrm{a} H I V:}$ human immunodeficiency virus

${ }^{\mathrm{b}} \mathrm{HCV}+$ : Hepatitis $\mathrm{C}$ virus positive

${ }^{\mathrm{C}} \mathrm{HCV}$-: Hepatitis $\mathrm{C}$ virus negative

other factors such as co-morbid addiction and mental illnesses. For patients with a history of drug use, a program-based addiction treatment [31] was required to initiate $\mathrm{HCV}$ treatment. Inmates who had a history of depression or another psychiatric disorder were referred to an on-site psychiatrist for evaluation. Prisoners with $\mathrm{HCV}$ genotype $1 \mathrm{~b}$ or with HIV infection were treated for 48 weeks, and those with genotypes 2 or 3 were treated for 24 weeks [32]. Individual treatment decisions were made by prison infectious disease physicians based on whether the expected length of stay was long enough to allow for the completion of a treatment course (24 to 48 weeks). Clinical indicators for treatment and funds available for the medications were also taken into consideration. Of those who received HCV treatment, 21 (84\%) had a history of drug use (11 opiate users, 5 stimulant users and 5 users of multiple drugs including opiates), 5 (20\%) were HIV infected, none was hepatitis B infected, 24 (96\%) had received hepatitis $B$ vaccination before treatment.
None of the patients had previous experience with interferon and ribavirin. The average age of treated patients was 35.5 years (range 29-45). Fifteen of 25 (60\%) treated patients underwent ultrasound-guided liver biopsies. The Metavir scoring system was used to classify fibrosis levels [33]. 11 (91.7\%) of those biopsied had no to mild fibrosis, 1 person had moderate (9\%) and $3(27.3 \%)$ had severe fibrosis of the liver. Of all the patients treated, $15(60 \%)$ were cured based on a negative HCV RNA test at the end of the treatment and 6 months after the treatment; $4(16 \%)$ relapsed based on a negative HCV RNA at the end of the treatment and positive HCV RNA test 6 months after the treatment (3 patients with genotype $3 \mathrm{a}$, one with $1 \mathrm{~b}) ; 3$ (12\%) were unresponsive to treatment based on an HCV RNA test at 24 weeks of treatment (all with genotype 3a); 1 person (4\%) stopped treatment; and treatment outcome data were missing for $2(8 \%)$ of the patients as they had been released from prison.

Table 2 Factors associated with hepatitis C infection among newly admitted prisoners in Estonia, 2014 to 2015, univariate and multivariable logistic regression analyses $(n=1845)$

\begin{tabular}{|c|c|c|c|c|}
\hline \multirow[t]{2}{*}{ Variable } & \multicolumn{2}{|c|}{ Bivariable analysis } & \multicolumn{2}{|c|}{ Multivariable analysis } \\
\hline & $\overline{O R^{c}}$ & $\mathrm{Cl}^{\mathrm{b}}(95 \%)$ & Adjusted $O R$ & Cl (95\%) \\
\hline Age & 1.01 & $1.00-1.02^{* * *}$ & 1.01 & $1.00-1.02^{* * *}$ \\
\hline Gender (female) & 1.09 & $0.73-1.63$ & 1.30 & $0.79-2.15$ \\
\hline Tattoo (yes) & 1.54 & $1.25-1.90^{* * *}$ & 0.81 & $0.62-1.04$ \\
\hline Drug use history (yes) & 8.49 & $6.87-10.49^{* * *}$ & 6.51 & $5.12-8.28^{* * *}$ \\
\hline HIV infected (yes) & 4.62 & $3.59-5.96^{* * *}$ & 2.56 & $1.92-3.43^{* * *}$ \\
\hline Previous incarceration (yes) & 3.2 & $2.61-3.93^{* * *}$ & 3.16 & $2.48-4.04^{* * *}$ \\
\hline
\end{tabular}

*** $p$-value $<0.01$ 


\section{Discussion}

To our knowledge, this is the first study focusing on HCV prevalence and $\mathrm{HCV}$ treatment outcomes in the entire prison population of a European country. The studies that do exist are often restricted to individual prisons or subgroups of prisoners [2].

We found high HCV seropositivity rates (56\%) among newly imprisoned individuals in Estonia. HCV seropositivity among newly incarcerated and tested prisoners (with either unknown HCV status or previous negative HCV test) was $35 \%$. These prevalence figures are consistent with those from Italy (38\%) [34] and Scotland (19\%) [35], where available data suggest that $\mathrm{HCV}$ is highly prevalent among prisoners.

The risk factors for $\mathrm{HCV}$ seropositivity we observed (drug use, previous incarceration, HIVstatus, age) are in accordance with previous research $[1,2,8,14,36]$. According to previous studies in other countries, the main risk factor associated with $\mathrm{HCV}$ infection in prison populations is IDU $[1,2,8,37]$. In our study, the odds for being $\mathrm{HCV}$-positive were about three times higher among HIV-positive than HIV-negative prisoners. HIV and HCV share common routes of transmission, and are therefore expected to some extent co-infect the same individuals.

Previous incarceration has been significantly associated with HCV infection in studies from Australia, England, and Wales [36-38]. Multiple incarcerations were also found to be a risk factor for HCV seropositivity in our study. The contribution of $\mathrm{HCV}$ transmission in prison to the overall disease burden among PWID is difficult to document owing to uncertainties regarding precise date of infection and risk behaviours in the community (both prior to and post-incarceration). The role of prisons as a risk environment for the reinforcement, concentration and amplification of infections such as HIV and HCV has been suggested [39].

In our study, the seropositivity of $\mathrm{HCV}$ was higher among those with tattoos. However, this association was lost while adjusting for potential confounders. It is known that tattooing is common in prisons and jails [10] and prisoners who acquired their tattoos in prisons are more likely to be HCV-infected $[1,12,34]$. The risks and benefits of legal tattooing in prison should be discussed. Evidence from studies on the relationship between tattooing and HCV transmission in prisons appears to be mixed. Some studies report significant correlations [10, 36, 40] while others do not [41].

We found the presence of hepatitis $\mathrm{C}$ antibodies in 12 individuals $(0.6 \%)$ who were HIV negative and had no records indicative of drug use. While we do not have data on other HCV risk factors (such as history of blood transfusion, high risk sexual behviour), all of the 12 prisoners had tattoos. Eight of them had acquired their tattoos while in prison during the Soviet era (personal communication with prisoners). One might speculate that the traditions of tattooing in prisons have changed (there appear to be fewer tattoos among more recent prison populations and drug using individuals).

Data on the relationship between $\mathrm{HCV}$ and gender in prison populations is also conflicting. In some studies, $\mathrm{HCV}$ infection was observed more frequently in incarcerated women than in incarcerated men. [1,3]. Other studies did not find the same result [42]. In our study, after accounting for other risk factors, gender did not emerge to be associated with HCV seropositivity.

Screening strategies based on risk factors have traditionally failed to identify all patients at risk of infection, leaving a sizable proportion of patients unaware of their infection. We observed that a screening system for $\mathrm{HCV}$ case finding relying only on known risk factors misses a sizeable proportion of newly incarcerated individuals with $\mathrm{HCV}$ infection. The all-inclusive $\mathrm{HCV}$ testing strategy identified $37.7 \%$ more $\mathrm{HCV}$ infection cases among the newly incarcerated than would have been detected on the basis of known risk factors (drug use history, HIV infected status) screening.

In our study, the main HCV genotypes were $3 \mathrm{a}(n=172$, $44 \%)$ and $1 \mathrm{~b}(n=135,35.2 \%)$. HCV genotypes have geographically distinct distributions. HCV genotype 1 and 3 infections are globally more prevalent than all other genotypes. Those genotypes, more commonly found in lower-income countries, account for a significant proportion of HCV cases worldwide [43]. Meyer et al. found that genotype 3 prevailed in prisoners from the independent states of the former Soviet Union [44]. Tyczyno et al. compared the HCV genotyping performed on Polish prisoners and hospital patients, and found that HCV genotype 3 prevailed in the prisoners $(60.1 \%)$ and genotype 1 in patients at large (79.6\%). This distinction is most probably due to the fact that genotype 3 is more frequent in PWID [45]. In Estonia, the following distribution of genotypes was documented among hospital patients: genotype $1 \mathrm{~b}$ was found in $32 \%$ of the patients, $3 \mathrm{a}$ was found in $20 \%$, $2 \mathrm{a}$ in $12 \%$, and $1 \mathrm{a} / \mathrm{b}$ (double infection) in 28\% [46]. Among the Estonian prisoners tested for HCV genotypes nearly two decades later, we were unable to replicate the finding of $1 \mathrm{a} / \mathrm{b}$ double infection occurrence.

The response to antiviral treatment in prisoners is similar to that of the general population [1]. Our study observed a $60 \%$ sustained viral response among treated prisoners. Importantly, this result does not differ from the treatment response reported from the community (in a hospital setting in Estonia) where a $60.3 \%$ sustained treatment response was achieved [47]. This suggests that acceptable $\mathrm{HCV}$ treatment outcomes can be achieved in prisons. There are clear advantages to $\mathrm{HCV}$ treatment in prison settings. In-prison, treatment provides the opportunity to access population groups for whom treatment options may 
be limited after release. Treatment in prisons occurs in controlled, directly observed settings, potentially achieving increased compliance and monitoring for side effects and complications [48, 49].

Our study has some strengths and limitations. A key feature of our study is the all-inclusive testing strategy and national coverage of the data collection. This is different from other, similar studies $[11,12,14]$ conducted in the region because testing was offered and data were collected from all new prisoners entering all Estonian prisons. However, given the nature of the data used, we were unable to determine the frequency or duration of drug injection and, particularly importantly, distinguish between injecting and other types of drug use. Thus, some of the important details might have been lost. Importantly, we were unable to assess the impact of other potential HCV risk factors (such as sexual behaviour and previous blood transfusions, or surgery).

\section{Conclusions}

Case finding for $\mathrm{HCV}$ infection in prisons, $\mathrm{HCV}$ treatment and educational programmes to discourage high-risk behaviours might help curtail the rise in HCV infection in prison populations. Our study suggests that $\mathrm{HCV}$ treatment in infected inmates is feasible and the results (sustained viral response achievement) do not differ from that in the community.

Reducing HCV prevalence among prisoners has the potential to reduce the burden of disease in the general public in the community. When developing HCV screening strategies in prisons, policy-makers should consider the risk factors that we have highlighted in our study.

Our findings have several implications: they show that (i) universal $\mathrm{HCV}$ testing at prisonentry has the potential to increase the number of people who are aware of their infection, (ii) there is a need to scale up comprehensive $\mathrm{HCV}$ care to those infected. We believe that the results of this study might be applicable to other countries in the region that have witnessed injection drug use and related HIV epidemics in the late 1990s and early 2000s.

\section{Abbreviations \\ AOR: Adjusted odds ratio; ART: Antiretroviral therapy; Cl: Confidence interval; DAA: Direct-acting antivirals; HCV: Hepatitis C virus; HIV: Human immunodeficiency virus; IDU: Injection drug use; NSP: Needle and syringe exchange programmes; OR: Odds ratio; OST: Opioid substitution therapy; PWID: People who inject drugs}

\section{Availability of data and materials}

The datasets used and analyzed during the current study are available from the corresponding author on reasonable request.

\section{Authors' contributions}

Authors KK, AU were involved in the design of the study. KK abstracted the data from databases and conducted data analysis. $J$ and KO participated in manuscript writing and revision. All authors revised and approved the manuscript.

\section{Ethics approval and consent to participate}

The study procedures were in accordance with local data protection regulations, and the study was approved by the Tartu University Research Ethics Committee. The analysis was based on preexisting records containing pseudo identification codes which allows tracking care provided to this person but not personal identification. Informed consent was deemed unnecessary according to national regulations.

\section{Consent for publication}

Not applicable.

\section{Competing interests}

The authors declare that they have no competing interests.

\section{Publisher's Note}

Springer Nature remains neutral with regard to jurisdictional claims in published maps and institutional affiliations.

\section{Author details}

${ }^{1}$ National Institute for Health Development, 42, 11619 Tallinn, Hiiu, Estonia. 2Department of Family Medicine and Public Health, University of Tartu, Ravila 19, 50411 Tartu, Estonia. ${ }^{3}$ Barcelona Institute for Global Health (ISGlobal), Hospital Clínic, University of Barcelona, Carrer de Casanova, 143, 08036 Barcelona, Spain. ${ }^{4} \mathrm{CHIP}$, Rigshospitalet, University of Copenhagen, Blegdamsvej 9, DK-2100 Copenhagen, Denmark. ${ }^{5}$ West Tallinn Central Hospital, Infectious Diseases Clinic, Paldiski maantee 68, 10617 Tallinn, Estonia.

Received: 18 December 2017 Accepted: 5 July 2018

Published online: 21 July 2018

\section{References}

1. Zampino R, Coppola N, Sagnelli C, Di Caprio G, Sagnelli E. Hepatitis C virus infection and prisoners: epidemiology, outcome and treatment. World $\mathrm{J}$ Hepatol. 2015:7(21):2323-30.

2. Dolan K, Wirtz AL, Moazen B, Ndeff o-mbah M, Galvani A, Kinner SA, et al. Global burden of HIV, viral hepatitis, and tuberculosis in prisoners and detainees. Lancet. 2016;388:1089-102.

3. Solomon L, Flynn C, Muck K, Vertefeuille J. Prevalence of HIV, syphilis, hepatitis $B$, and hepatitis $C$ among entrants to Maryland correctional facilities. J Urban Health. 2004:81:25.

4. Macalino GE, Vlahov D, Sanford-Colby S, Patel S, Sabin K, Salas C, et al. Prevalence and incidence of HIV, hepatitis B virus, and hepatitis $C$ virus infections among males in Rhode Island prisons. Am J Public Health. 2004; 94(7):1218-23.

5. Fox RK, Currie SL, Evans J, Wright TL, Tobler L, Phelps T, et al. Hepatitis $C$ virus infection among prisoners in the California state correctional system. Clin Infect Dis. 2005:41(2):177-86.

6. European Monitoring Centre for Drugs and Drug Addiction. Prisons and drugs in Europe: the problem and responses. Luxembourg: Publications Office of the European Union; 2012. Accessed 1 Sept 2015

7. Vescio MF, Longo B, Babudieri S, Starnini G, Carbonara S, Rezza G, et al. Correlates of hepatitis $C$ virus seropositivity in prison inmates: a metaanalysis. J Epidemiol Community Health. 2008;62(4):305-13.

8. UNAIDS. UNAIDS report on the AIDS global epidemic 2013 (appendix). Geneva: Joint United Nations Programme on HIV/AIDS; 2013.

9. Tohme RA, Holmberg SD. Transmission of hepatitis C virus infection through tattooing and piercing: a critical review. Clin Infect Dis. 2012; 54:1167-78.

10. Hellard ME, Aitken CK, Hocking JS. Tattooing in prisons - not such a pretty picture. Am J Infect Control. 2007;35:477-80.

11. Brandolini M, Novati S, De Silvestri A, Tinelli C, Patruno SF, Ranieri R, et al. Prevalence and epidemiological correlates and treatment outcome of HCV infection in an Italian prison setting. BMC Public Health. 2013:13:981.

12. Pourahmad M, Javady AA, Karimi I, Ataei B, Kassaian N. Seroprevalence of and risk factors associated with hepatitis B, hepatitis $C$, and human immunodeficiency virus among prisoners in Iran. Infect Dis Clin Pract. 2007:15:368-72

13. Briggs ME, Baker C, Hall R, Gaziano JM, Gagnon D, Bzowej N, et al. Prevalence and risk factors for hepatitis $\mathrm{C}$ virus infection at an urban veterans' administration medical center. Hepatology. 2001;34:1200-5. 
14. Nokhodian Z, Ataei B, Kassaian N, Yaran M, Hassannejad R, Adibi P. Seroprevalence and risk factors of hepatitis $C$ virus among juveniles in correctional center in Isfahan, Iran. J Prev Med. 2012;3(Suppl1):S113-7.

15. Borrill, J., Maden, A., Martin, A., Weaver, T., Stimson, G., Farrell, M. and Barnes, T. Differential substance misuse treatment needs of women, ethnic minorities and young offenders in prison: prevalence of substance misuse and treatment needs (2003). (Available online).

16. Fazel $\mathrm{S}$, Bains $\mathrm{P}, \mathrm{Doll} \mathrm{H}$. Substance abuse and dependence in prisoners: a systematic review. Addiction. 2006;101:181-91.

17. UNODC (2008), Drug dependence treatment: interventions for drug users in prison, United Nations Office on drugs and Crime, Vienna (available online).

18. Jakobsen JC, Nielsen EE, Feinberg J, Katakam KK, Fobian K, Hauser G, et al. Direct-acting antivirals for chronic hepatitis C. Cochrane Database Syst Rev. 2017;6:CD012143. https://doi.org/10.1002/14651858.CD012143.pub2.

19. Feld JJ, Jacobson IM, Sulkowski MS, Poordad F, Tatsch F, Pawlotsky JM Ribavirin revisited in the era of direct-acting antiviral therapy for hepatitis $C$ virus infection. Liver Int. 2017;37:5-18.

20. Allen SA, Spaulding AC, Osei AM, et al. Treatment of chronic hepatitis $C$ in a state correctional facility. Ann Intern Med. 2003:138:187-90.

21. Farley J, Vasdev S, Fischer B, et al. Feasibility and outcome of HCV treatment in a Canadian federal prison population. Am J Public Health. 2005;95:1737-9.

22. Sterling RK, Hofmann CM, Luketic VA, et al. Treatment of chronic hepatitis C virus in the Virginia Department of Corrections: can compliance overcome racial differences to response? Am J Gastroenterol. 2004;99:866-72.

23. Arain A, Robaeys G, Stöver H. Hepatitis C in European prisons: a call for an evidence-informed response. BMC Infect Dis. 2014;14(Suppl 6):S17. https:// doi.org/10.1186/1471-2334-14-S6-S17.

24. Spaulding AC, Thomas DL. Screening for HCV infection in jails. JAMA. 2012; 307(12):1259-60. https://doi.org/10.1001/jama.2012.374.

25. Council of Europe Annual Penal Statistics. Available from: http://wp.unil.ch/ space/space-i/prison-stock-on-1st-january/prison-stock-on-01-jan-2015-2016/. Accessed: 10 Nov 2017.

26. Uusküla A, Des Jarlais DC, Raag M, Pinkerton SD, Feelemyer J. Combination prevention for persons who inject drugs in the HIV epidemic in a transitional country: the case of Tallinn, Estonia. AIDS Care. 2015;27(1):10511. https://doi.org/10.1080/09540121.2014.940271.

27. European Monitoring Centre for Drugs and Drug Addiction. Preventing fatal overdoses: a systematic review of the effectiveness of take-home naloxone, EMCDDA Papers. Luxembourg: Publications Office of the European Union; 2015.

28. Kivimets K, Uusküla A. HIV testing and counselling in Estonian prisons, 2012 to 2013: aims, processes and impacts. Euro Surveill. 2014;19(47):20970.

29. Foreign support. Projects funded from European economic area and Norway grants. Tallinn: Estonian Ministry of Justice. Available from: http:// www.just.ee/en/foreign-support. Accessed: 10 Nov 2015.

30. Vanglateenistus. [Prison Service]. Uimastiseire. [Drug Monitoring Report 2014]. Tallinn: Estonian Ministry of Justice; 2014.

31. Social Rehabilitation Programmes for Offenders. Prison Service. Prisons Department of Ministry of Justice. Tallinn: Estonian Ministry of Justice. http://www.vangla.ee/en/socialwork/social-rehabilitation-programmesoffenders. Accessed 24 Jan 2015.

32. Kroonilise C- hepatiidi ravijuhend. (National Guidelines on treatment of HCV). Tallinn: Estonian Society of Gastroenterology and the Estonian Society for Infectious Diseases in 2006 and updated in 2007 and 2010. http://www.esid.ee/ cms/tl_files/failid/failid/Kroonilise\%20C-hepatiidi\%20\%20ravijuhend\%202010.pdf.

33. Bedossa P, Poynard T. An algorithm for the grading of activity in chronic hepatitis C. The METAVIR Cooperative Study Group. Hepatology. 1996;24:289-93.

34. Babudieri S, Longo B, Sarmati L, Starnini G, Dori L, Suligoi B, et al. Correlates of HIV, HBV and HCV infections in a prison inmate population: results from a multicenter study Italy. J Med Virol. 2005;76(3):311-7. https://doi.org/10. 1002/jmv.20375

35. Taylor A, Munro A, Allen E, Dunleavy K, Cameron S, Miller L, Hickman M. Low incidence of hepatitis $C$ virus among prisoners in Scotland. Addiction. 2013;108:1296-304.

36. Hellard ME, Hocking JS, Crofts N. The prevalence and the risk behaviours associated with the transmission of hepatitis $C$ virus in Australian correctional facilities. Epidemiol Infect. 2004;132:409-15.

37. Butler T, Boonwat L, Hailstone S, Falconer T, Lems P, Ginley T, et al. The 2004 Australian prison entrants' blood-borne virus and risk behaviour survey. Aust N Z J Public Health. 2007;31:44-50.
38. Weild AR, Gill ON, Bennett D, Livingstone SJ, Parry JV, Curran L. Prevalence of HIV, hepatitis B, and hepatitis C antibodies in prisoners in England and Wales: a national survey. Commun Dis Public Health. 2000;3:121-6.

39. Altice FL, Azbel L, Stone J, et al. The perfect storm: incarceration and the high-risk environment perpetuating transmission of HIV, hepatitis C virus, and tuberculosis in Eastern Europe and Central Asia. Lancet (London, England). 2016;388(10050):1228-48. https://doi.org/10.1016/ S0140-6736(16)30856-X.

40. Jafari S, Copes R, Baharlou S, Etminan M, Buxton J. Tattooing and the risk of transmission of hepatitis C: a systematic review and meta-analysis. Int J Infect Dis 2010;14(11):e928-40. https://doi.org/10.1016/j.ijid.2010.03.019.

41. Miller ER, Bi P, Ryan P. Hepatitis C virus infection in south Australian prisoners: seroprevalence, seroconversion, and risk factors. Int J Infect Dis. 2009;13(2):201-8. https://doi.org/10.1016/j.ijid.2008.06.011.

42. MAM P, Bandeira LM, Pompilio MA, Croda J, GRd R, LFP D, et al. Prevalence and Incidence of HCV Infection among Prisoners in Central Brazil. PLoS ONE. 2017;12(1):e0169195.

43. Messina JP, Humphreys I, Flaxman A, et al. Global distribution and prevalence of hepatitis C virus genotypes. Hepatology. 2015;61(1):77-87. https://doi.org/10.1002/hep.27259.

44. Meyer MF, Wedemeyer H, Monazahian M, Dreesman J, Manns MP, Lehmann M. Prevalence of hepatitis $C$ in a German prison for young men in relation to country of birth. Epidemiol Infect. 2007;135:274-80.

45. Tyczyno M, Halota W, Nowak W, Pawlowska M. Distribution of HCV genotypes in the populations of inmates in polish prison potulice and patients hospitalized in Bydgoszcz. Hepat Mon. 2014;14:e14559.

46. Tallo $T$, Lappalainen M, Tefanova V, Priimagi I. Distribution of hepatitis C virus genotypes in patients with chronic hepatitis $C$ in northern Estonia. Acta Virol. 2000;44:175-8.

47. Brjalin V, Salupere R, Tallo T, Kuznetsova T, Priimägi L, Tefanova V. Efficacy of peginterferon alpha-2A and ribavirin combination therapy in treatment-naive Estonian patients with chronic hepatitis C. Cent Eur J Public Health. 2012;20(2):150-5.

48. Negro F. Epidemiology of hepatitis C in Europe. Dig Liver Dis. 2014; 46(Suppl. 5):S158e64

49. Stone J, Martin NK, Hickman M, et al. Modelling the impact of incarceration and prison-based hepatitis $\mathrm{C}$ virus ( $\mathrm{HCV}$ ) treatment on $\mathrm{HCV}$ transmission among people who inject drugs in Scotland. Addiction (Abingdon, England). 2017;112(7):1302-14. https://doi.org/10.1111/add.13783.

\section{Ready to submit your research? Choose BMC and benefit from:}

- fast, convenient online submission

- thorough peer review by experienced researchers in your field

- rapid publication on acceptance

- support for research data, including large and complex data types

- gold Open Access which fosters wider collaboration and increased citations

- maximum visibility for your research: over $100 \mathrm{M}$ website views per year

At BMC, research is always in progress.

Learn more biomedcentral.com/submissions 